\title{
Tüketicilerin Sosyal Medya Pazarlama Aktivitelerine Katılımlarının Etkileyicileri ve Sonuçları
}

\author{
The Antecedents and Consequences of Consumers' Participations in Social \\ Media Marketing Activities
}

\author{
Sertaç ÇiFCi', Doğukan SÖZEN²
}

\begin{abstract}
ÖZET
İşletmeler açısından tüketicilerin sosyal medya pazarlama aktivitelerine katılımlarını etkileyen faktörler ve katııımlarının sonuçlarının bilinmesi oldukça önemlidir. Bu çalışmanın amacl; (1) tüketicilerin sosyal medya aktivitelerine katılımlarının nedenleri, (2) katılımlarının etkileyicileri ve (3) sonuçları araştırımasıdır. Literatür taraması sonucunda ortaya çıkan modelin ve hipotezlerin sınanması için nicel bir araştırma yöntemi seçilmiştir. Anket yöntemi ile iki farklı ürün grubundan ikişer marka seçilerek uygulama yapılmış ve 344 katılımcıdan veriler toplanmıştır. Analiz için SPSS ve Lisrel paket programları aracılığılla açıklayıcı ve doğrulayıcı faktör analizleri ile yapısal eşitlik analizi kullanıımıştır. Çalışma sonuçlarında eğlence, etkileşim, modayı takip ve kişiselleştirme nedenleri ile tüketicilerin sosyal medya pazarlama aktivitelerine katılım gösterdikleri bulunmuştur. Katılımı olumlu etkileyen faktörler ise tüketicilerin marka güveni ve hatırlamaya değer tecrübeleridir. Tüketicilerin katılımları ne kadar artar ise ise satın alma niyeti ve kulaktan kulağa iletişim eğilimleri de o derece de artmaktadır.
\end{abstract}

Anahtar Kelimeler: Sosyal medya pazarlama aktiviteleri; hatılamaya değer tecrübeler; marka güveni; ürün ilgilenimi; tekrar satın alma niyeti ve kulaktan kulağa iletişim.

\section{GíRiş}

Günümüzde etkili pazarlama iletişimi için sosyal medyanın önemi işletmeler tarafından daha sıklıkla fark edilmekte ve adeta tutundurma araçlarının beşincisi olarak yerini almaktadır (Mangold ve Faulds, 2009). Bireyler uyumadıkları zamanın üçte birini

\begin{abstract}
Learning the antecedents and consequences of consumers' participations in social media marketing activities is very important for the firms. The aims of this study are to investigate (1) the reasons consumers participate in social media activities (2) factors affecting this participation (3) consequences of this participation that the firms get. After a comprehensive literature review, a research model was developed and hypotheses based on literature reviewed were developed and tested following quantitative method. Two brands in two different product categories were selected and quantitative data was collected from 344 participants via a questionnaire. Exploratory and confirmatory analyses were conducted using SPSS and LISREL and a structural equation modelling was run. The findings showed that consumers participate firms' social media marketing activities because of the entertainment, interaction, customization and keeping up with the fashion. Brand trust and memorable experiences affect consumers' participation on social media marketing activities. Finally this study revealed that the more participations on social media marketing activities are the more consumers' re-purchase intention and word-of-mouth communication.
\end{abstract}

Keywords: Social media marketing activities; memorable experiences; brand trust; product involvement; re-purchase intention and word-ofmouth communication. 
anın kavramsal açıklamasını yapmaya çalıştı̆̆ımızda, katılımcıların bilgi ve görüşlerini paylaşmak için birbirleri ile çevrimiçi etkileşimine izin veren çift yönlü bir iletişim platformu tanımı ön plana çıkmaktadır (Kim ve Ko, 2012). İşletmeler açısından pek çok fayda barındıran sosyal medyaya tüketicilerin katılım nedenleri ve katılımlarının artırılması en başta üzerinden durulması gereken konuların başında gelmektedir. $\mathrm{Bu}$ çalışmada ele alınan geniş problem alanı, işletmelerin daha etkili sosyal medya pazarlama aktiviteleri için neler yapmaları gerektiği, katılımların etkileyicilerinin ve sonuçlarının öğrenilmesidir. Literatür taraması sonucunda araştırma problemleri olarak; tüketicilerin sosyal medya pazarlama aktivitelerine katılım nedenleri nelerdir? Tüketicilerin sosyal medya pazarlama aktivitelerine katılımlarını etkileyen faktörler nelerdir? ve tüketicilerin sosyal medya pazarlama aktiviteleri sonucunda hangi değişkenler etkilenmektedir? olarak belirlenmiştir. Tüketicilerin, işletmelerin sosyal medya aktivitelerine katılım sebepleri konusunda eğlence, etkileşim, modayı takip yani trend olması, kişiselleştirme ve sosyal medya araçlarını kullanarak kulaktan kulağa iletişim en başta gelenleridir (Kim ve Ko, 2012). Tüketiciler, işletmelerin sosyal medya araçlarının içeriğini ve kendisini eğlenceli buldukları için, bilgiye ulaşmak ve diğerlerinden ürünler hakkında bilgi toplamak için, modayı takip etmek için, kişiselleştirme şansı verdiği için katılım göstermektedir. Bunun yanı sıra, tüketicilerin işletmelerin sosyal medya araçlarına katılımlarının etkileyicileri ve sonuçları da önemlidir.

Yapılan literatür taraması sonucunda, bu katılımın belirleyicileri olabilecek olan marka güvenin (Chiu vd. 2010), hatırlamaya değer tecrübeler (Youl-Ha ve Perks, 2005) ile ürün ilgilenimi (Warrington ve Shim, 2000) çalışmada ele alınan kavramlardır. Bunun yanında, tüketicilerin sosyal medya pazarlama aktivitelerine katılımlarının işletmeye olacak faydalarına bakıldığında ise iki kavram ön plana çıkmaktadır. Bunlar, kulaktan kulağa iletişim ve yeniden satın alma niyetidir (Zeithaml vd. (1996). Yapılan bu çalışmanın önemi, işletmelerin daha etkin sosyal medya pazarlama stratejilerinde neden, etkileyici ve sonuç olarak görmeleri gereken kavramları ortaya koyabilmektir. Bu çalışmanın üç temel amacı vardır. İlki, Kim ve Ko, (2012)'nun geliştirdiği tüketicilerin sosyal medya pazarlama aktivitelerine katılımlarının nedenlerini ortaya koydukları çalışmanın seçilen ürün grupları ve farklı bir kültürde değerlendirilmesinin yapılmasıdır. İkinci amaç, bu değerlendirme sonrasında tüketicilerin sosyal medya pazarlama aktivitelerine katılım-
Iarının nedenlerini belirleyebilecek marka güveni, hatırlamaya değer tecrübeler ve ürün ilgilenimin etkisinin belirlenmesidir. Çalışmanın üçüncü amacı ise tüketicilerin sosyal medya pazarlama aktivitelerine katılımlarının sonuçları yani bir bakıma işletmeye faydalarıdır. Burada araştırılan kavramlar ise kulaktan kulağa iletişim ile yeniden satın alma davranışlarıdır. Bu çalışmanın literatüre katkısı Kim ve Ko (2012)'nun ele aldığı şekli ile tüketicilerin sosyal medya pazarlama aktivitelerine katılımı farklı bir ürün grubu ve kültür için değerlendirilmesi ile dış geçerliliğinin ortaya konulmasıdır. Diğer fayda ise yazarlarında belirtiği üzere bu değişkenlerine etkileyicilerinin ve sonuçlarının ne olabileceğinin literatür taraması ve nicel bir araştırma ile belirlenmesidir. Takip eden bölümde tüketicilerin sosyal medya pazarlama aktivitelerine katılımlarının nedenleri, etkileyicileri ile sonuçları üzerinde durulacak ve araştırma modeli sunulacaktır. Daha sonra araştırma modelinin doğruluğunun sınanabilmesi amacıyla nicel bir araştırma gerçekleştirilmiş ve çalışma sonuçları ile de bulgular tartışılmıştır.

\section{KAVRAMSAL ÇERÇEVE}

Bütünleşik pazarlama iletişiminde tüm araçların uyumlu bir şekilde kullanılması ve dört temel tutundurma aracının yanında adeta bir "hybrid" olan sosyal medyanın önemi oldukça fazladır (Mangold ve Faulds, 2009). İşletmeler bu önem nedeniyle pazarlama stratejilerini sosyal medya kullanımına uygun hale getirmişlerdir (Kim ve Ko, 2012). Tüketiciler de kendi aralarındaki iletişimde markaların pazarlama aktivitelerinde aktif rol oynarlar. Markaların yaptığı paylaşımlarda onlara karşı çeşitli tutum ve tavırlar sergileyebilir, kulaktan kulağa iletişimle kampanyaların seyrini değiştirebilirler. Kısacası markalar sosyal medyada pazarlama aktivitelerini gerçekleştirirken, tüketiciler sosyal medyanın her anında ve platformundaki varlıkları ile bu sürecin temel taşlarından olmaktadırlar. Bu çalışmada, tüketicilerin sosyal medya pazarlama aktivitelerine katılım konusunda Kim ve Ko'nun 2012 yılında Journal of Business Research'de yayınlanan araştırması başlangıç noktası olarak ele alınmıştır. Tüketicilerin, işletmelerin uyguladıkları sosyal medya pazarlama aktivitelerine katılımı beş yapı içerisinde değerlendirmişlerdir; eğlence, etkileşim, medya takip, kişiselleştirme ve sosyal medyayı kullanarak kulaktan kulağa iletişim. Tüketiciler, temel olarak bu beş faktör sebebi ile sosyal medya araçlarını kullanmaktadır. Aslında bu boyutlar, işletmelerin nasıl bir sosyal medya aracı ve içeriği 
seçmesi açsısından da önemlidir. Eğlence; işletmelerin sosyal medya araçlarının ve içeriklerinin, tüketiciler tarafından eğlenceli ve ilgi çekici bulunması anlamına gelmektedir. Tüketiciler, eğlenceli buldukları ve güzel vakit geçirebilecekleri sosyal medya araçlarını tercih etmektedir. Etkileşim, sosyal medya araçlarının tüketicilere, diğer tüketiciler ve işletmeler ile sohbet etme, fikir ve bilgi paylaşma imkânı vermesidir. Tüketiciler açısından oldukça önemlidir. Ayrıca tüketicilerin görüşlerini doğrudan aktarma fırsatı bulabilmesidir. Sosyal medya araçları üzerinden kurulan etkileşimler ve verilen mesajlarla tüketici ile aslında bir ortaklık kurulmaktadır. Modayı Takip/Trend; Kimi tüketiciler en yeni bilgilere bir an önce ulaşmak isterler ve bu nedenle de sosyal medyayı takip ederler. Kişiselleştirme, sosyal medya araçlarının tüketicilere kişiselleştirilmiş bilgi ve hizmet sunmasıdır. Tüketici istediği bilgi ve hizmete ulaşabilir. Sosyal Medya Araçlarını Kullanarak Kulaktan Kulağa Iletişim, bazı tüketiciler arkadaşlarına marka, ürün veya hizmetler hakkında bilgi paylaşımı için sosyal medya araçlarını kullanabilir veya kendi sayfasında ya da bloğunda paylaşabilir (Kim ve Ko, 2012).

Aslında yukarıda sayılan bu beş boyut işletmeler açısından çok önemlidir. Bu boyutların ve hedef kitledeki tüketicilerin nelerden hoşlandıklarının bilinmesi, sosyal medya aracının nasıl izleneceğinin de anlaşılmasıdır. Güven, satın alma sürecinde önemli bir kavramdır (Powers vd. 2012). Marka güveni, geçmiş tecrübeler ile birlikte tüketicinin zaman içerisinde tecrübe ile öğrenme sürecidir. Bundan dolayı da, marka ile ilgili bilgi ve tecrübesinin özetidir (Delgado-Ballester ve Munuera-Aleman, 2005). Güçlü ve güvenilir bir marka, işletmenin ürünlerinin de güçlenmesi anlamına gelecektir (Norback, 2005). Basılı anlamda iyi tanınmış markalara sahip işletmeler, "halo etkisi" sayesinde internette yapacakları yeni uygulamalarda bunun faydasını göreceklerdir (Harvin, 2000). Tüketicilerin markaya yönelik güvenini artıkça, işletmelerin sosyal medya pazarlama aktivitelerine katılımlarının da artması beklenmektedir. Bunun sebebi, tüketicilerin güven düzeyinin artmasının, onlara ürün ve marka hakkında önemli bilgilerin de sunulması anlamına gelmektedir (Chiu vd. 2010). Tüketiciler, markaya güven duydukça, markanın sosyal medya araçlarına katılımları artacaktır.

H1= Marka güveni, tüketicilerin sosyal medya pazarlama aktivitelerine katılımlarını olumlu yönde etkilemektedir.
Tecrübe, belirli bir durum ile karşılaşıldığında göreceli olarak belirli bir şeye yönelik yüksek yakınlık gösterme durumdur (Braunsberger ve Munch, 1998). Tüketiciler genellikle bilgi arama, ürün veya hizmet satın alma kararlarında bu tecrübeyi kullanmaktadır (Youl-Ha ve Perks, 2005). Sosyal medya araçlarına katılım durumu da tüketicilerin işletme ile yaşamış olduğu tecrübeden etkilenmektedir.

H2= Hatırlamaya değer tecrübeler, tüketicilerin sosyal medya pazarlama aktivitelerine katılımlarını olumlu yönde etkilemektedir

Ürün ilgilenimi kavramı son yıllarda pazarlama içerisinde özellikle de iletişim, tüketici davranışları gibi konularda oldukça önemle üzerinde durulan bir kavram haline gelmiştir (Warrington ve Shim, 2000). Illgilenim tanım olarak algılanan kişisel ilgi/ alaka olarak ifade edilebilir (Celsi ve Olson, 1988). Aslında ürün ilgilenimi, tüketici davranışının temel belirleyici değişkenlerinden birisi olarak kullanılmaktadır (Dholakia, 1998). Bizim çalışmamızda ise sosyal medya pazarlama aktivitelerine katılım bir tüketici davranışı olarak ele alınmıştır. Yüksek ilgilenim gösteren tüketiciler, işletme, ürün, satış gibi konularda araştırma yapma konusunda daha çok motivedir (Warrington ve Shim, 2000). Bundan dolayı, o ürün grubuna yönelik ilgilenimi ne kadar yüksek olur ise, tüketicilerin o ürün grubunda ürün sunan işletmenin sosyal medya aktivitelerine katılımları da artacaktır.

H3= Ürün ilgilenimi, tüketicilerin sosyal medya pazarlama aktivitelerine katılımlarını olumlu yönde etkilemektedir

Zeithaml ve diğ. (1996)'ne göre tüketicilerin bir işletme ya da markaya yönelik beş davranışsal niyeti vardır. Bunlar; sadakat, özel bir fiyat düzeyinde ödeme istekliliği, kulaktan kulağa iletişim, şikâyetler ve tekrar satın alma niyetidir. Burada aslında aldıkları ürünlerden memnun kaldıklarında olması gereken sonuçlardır. Biz çalışmamızda bunlardan iki çıktıyı yani tekrar satın alma niyeti ve kulaktan kulağa iletişimi ele aldık. Tekrar satın alma niyeti, aynı işletme tarafından sunulan ürünleri tekrar satın alma değerlendirmesi olarak tanımlanmaktadır (Hellier vd. 2003). Kulaktan kulağa iletişim ise potansiyel, şimdiki veya daha önceki müşterilerin ürünler hakkındaki olumlu veya olumsuz ifadeleridir (Hennig-Thurau vd. 2004). İşletmelerin modern pazarlama anlayışındaki hedefi müşteri memnuniyeti ile satışlarını artırmak ve onlar ile uzun dönemli ilişkiler kurmaktır. Iş̧te bu noktada, tekrar satın alma niyeti beklenilen en 
önemli sonuçlardan birisidir. Kulaktan kulağa iletişim ise iletişim-tutundurma açısından en etkili araçtır. Bunun nedeni, kulaktan kulağa iletişimin işletmelerin uyguladıkları iletişim araçlarına göre daha güvenilir bulunmasıdır. Çünkü burada tüketiciler, "benim gibi insanlar" düşüncesi ile bu mesajlara daha çok güven duymaktadır (Allsop vd. 2007). Sosyal medya, tüketicilerin davranışları üzerinde olumlu bir etkiye sahiptir (Williams ve Cothrell, 2000). Bu açıklamalar ışığında aşağıdaki iki hipotez geliştirilmiştir.
H4= Tüketicilerin sosyal medya pazarlama aktivitelerine katılımları, kulaktan kulağa iletişimi olumlu yönde etkilemektedir.

H5= Tüketicilerin sosyal medya pazarlama aktivitelerine katıımları, tekrar satın alma niyetini olumlu yönde etkilemektedir.

Yukarıda açıklanan literatür ile birlikte araştırma modeli ve hipotezleri aşağıda gösterilmiştir.

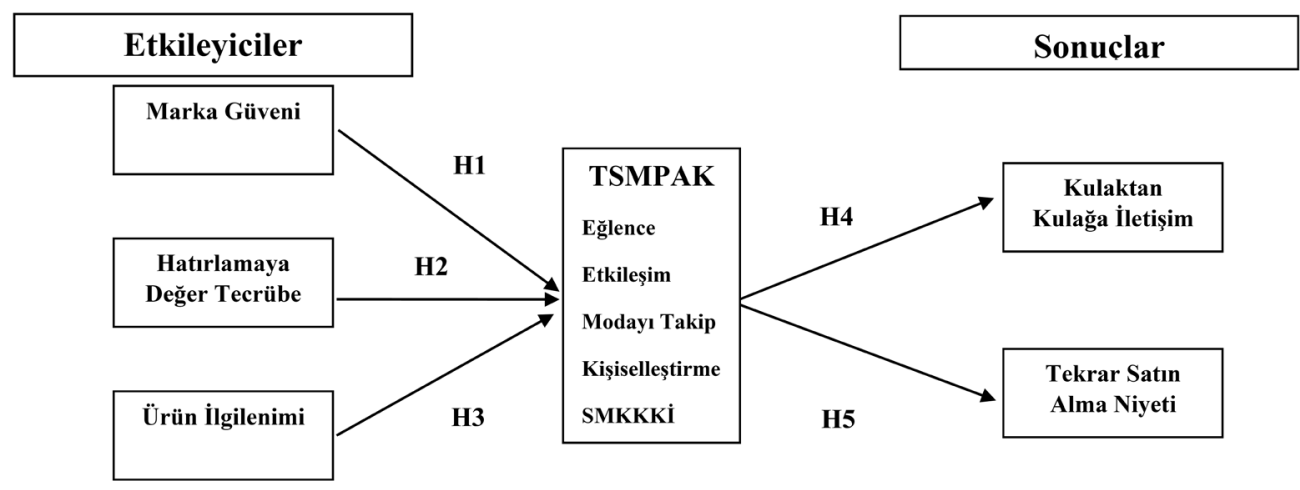

Şekil 1: Tüketicilerin Sosyal Medya Pazarlama Aktivitelerine Katılımlarının Nedenleri, Etkileyicileri ve Sonuçlarına İlişkin Araştırma Hipotezleri ile Modeli

\section{YÖNTEM}

Tüketicilerin sosyal medya pazarlama aktivitelerine katıımlarının etkileyicileri ve sonuçlarını ortaya konulması amaçlanan bu çalışmada, araştırma model ve hipotezlerin test edilmesi için nicel bir araştırma yöntemi tercih edilmiştir. Sosyal medyanın özellikle üniversite öğrencileri arasında yaygın kullanılmasından dolayı üniversite öğrencileri ana kütle olarak belirlenmiştir. Örnekleme yöntemi olarak kolayda örnekleme yöntemi seçilerek Amasya Üniversitesi lisans eğitimi alan öğrencileri içinde 600 kişi seçilmiştir. Anket aracılığıyla veriler öğrencilere yüz yüze anket yöntemi uygulanarak toplanmıştır. Araştırmacılar tarafından veri kalitesi kontrolleri yapılmış ve dört temel noktadan inceleme yapılmıştır. Örneklem hatasına düşmemek için 40 civarında anketin aslında üniversite öğrencileri tarafından değil çoğunlukla çalışanlar tarafından doldurulduğu tespit edilerek uygulama dışı bırakılmıştır. İkinci olarak anket formunda yer alan örtük değişkenlere ilişkin bazı sorular ters kod ile sorulmuştur. Yapılan kontroller sonucunda tutarsızlıklar saptanan 105 anket veri dışı bırakılmıştır. Üçüncü olarak ise boş bırakılan sorular içeren anket formları incelenmiştir. Bu formlar arasında özellikle de öznel yapılara ilişkin soruların boş bırakıldığı tespit edilen 55 anket uygulamaya dahil edilmemiştir. Son olarak ise anket formunda kontrol sorusu olarak, sosyal medyada ne kadar süre vakit geçiriyorsunuz sorusuna hiç cevabı veren 56 kişi de uygulama dışı bırakılmıştır. Böylelikle 344 geçerli veri ile analizler yapılmıştır. Anket formunda Ankete katılan cevaplayıcıların cinsiyetlerini, gelir durumlarını, sosyal medyada geçirdiği süreyi ve yaş ortalamasını belirlemek için frekans tablosu oluşturulmuştur. Tablo 1'de görüldüğü üzere örneklemi oluşturan katılımcıların $\% 69,2$ 'i kadın, \%30,8'i erkektir. Ailelerinin gelir durumlarına bakıldığında $\% 18,9$ 'unun geliri 0 - $1000 \mathrm{TL}$, \%46,5'inin 1001 - 2000 TL, \%24,4'ünün 2001 - 3000 TL, \%6,4'ünün 3001 - 4000 TL arasındadır. \%3,8'lik kısmın ise gelir düzeyi 4000 TL'nin üzerindedir. Sosyal medyada geçirilen süreler göz önünde bulundurulduğunda cevap verenlerin. $\% 46,8^{\prime}$ lik kesim 2 saate kadar, \%31,1'i 2 - 4 saat, \%13,7'si 4 - 7 saat aralığında sosyal medyada vakit geçirmektedir. \%8,4'lük kısım 7 saatinde üzerinde sosyal medyada vakit geçirmektedir. Araştırma verilerine göre anketi cevaplayan öğrencilerin yaş ortalaması 21,04'tür. Katılımcılara ait tanımlayıcı bu istatistiksel değerler aşağıdaki 
tabloda verilmiştir. Hazırlanıp uygulanan anket formu 3 bölümden oluşmaktadır. Cevaplayıcılara bu üç bölümde toplam 33 soru yöneltilmiştir. İlk bölümde cevaplayıcılara sorulan sorular ile akıllarına ilk olarak gelen sosyal medya araçlarını ve düzenli olarak kullandıkları sosyal medya mecralarını yazmaları istenmiş̧ir. Burada amaç çağrışımları ve sıkı kullanıcısı oldukları sosyal medya platformlarını tespit etmektir. İkinci bölüm kullandıkları markaların sosyal medya pazarlama aktivitelerine katılım düzeylerini ölçmek için sorulan 32 soruluk anket formundan oluşmaktadır. Üçüncü ve son bölümde cevaplayıcıların cinsiyetlerini, yaş dağılımlarını, sosyal medyada geçirdikleri süreyi ve aile gelir durumlarını ortaya çıkarmak amacıyla bir bilgi formu yer almaktadır. Anketin ikinci bölümünde algılanan sosyal medya pazarlama aktivitelerini ölçmek için Kim ve Ko (2012)'dan uyarlanan on bir soru, tekrar satın alma niyetini ölçmek için Carroll ve Ahuvia (2006), Chaudhuri ve Holbrook (2001)'dan uyarlanan üç soru, kulaktan kulağa iletişimi ölçmek için Stokburger-Sauer, vd.(2012)'den uyarlanan üç soru, ürün / hizmet ilgilenimini ölçmek için Helmig vd. (2007)'den üç soru, markaya yönelik güveni ölçmek için Chaudhuri ve Holbrook (2001)'den uyarlanan dört soru, hatırlamaya değer tecrübeleri ölçme için
Agapito vd. (2013)'den uyarlanan üç soru yer almaktadır. Cevaplayıcılara bu sorular 7'li Likert tipi tatmin ölçeği ile sorulmuştur. Ölçek 7=Kesinlikle katılıyorum, $1=$ Kesinlikle katılmıyorum şeklinde hazırlanmıştır. Cevaplayıcıların 1'den 7'ye kadar soruları değerlendirmeleri, katılma derecelerine bir rakam işaretlemeleri istenmiştir. Anket gerçekleştirilmeden önce 50 Amasya Üniversitesi lisans öğrencisine 6 sorudan oluşan bir ön test uygulanmıştır. Bu ön testtin ilk iki sorusunda cevaplayıcıların akıllarına ilk gelen sosyal medya araçları ve düzenli olarak hangilerini kullandıkları sorulmuştur. Diğer iki soruda akıllarına ilk olarak gelen GSM operatörleri ve spor giyim markaları sorulmuş̧ur. Son iki sorudaysa akıllarına gelen GSM operatörleri ve spor giyim markaları arasından web sayfalarında etkinlik, internette görünürlük, arama motoru görünürlüğü, sosyal medya üzerinde markanın içeriği, etkisi ve akıllı telefonlarda uygulama kullanımı kriterlerine uygun bir markayı seçmeleri istenmiştir. Bu ön test sonucunda iki GSM operatörü (Turkcell ve Vodafone) ile iki spor giyim markası (Adidas ve Nike) olmak üzere dört marka ortaya çıkmıştır. Bu ön test sonuçları ışığında 600 kişiye uygulanan anket dörde bölünmüş ve bu Turkcell, Vodafone, Adidas ve Nike markalarının kullanıcılarına ulaşılmıştır.

Tablo 1: Katılımcılara Ait Tanımlayıcı İstatistik Değerler

\begin{tabular}{llcc}
\hline & & Frekans & Yüzde \\
\hline Cinsiyet & Kadın & 238 & 69,2 \\
& Erkek & 106 & 30,8 \\
Gelir Durumu & $\mathbf{0 - 1 0 0 0}$ & 65 & 18,9 \\
& $\mathbf{1 0 0 1 - 2 0 0 0}$ & 160 & 46,5 \\
& $\mathbf{2 0 0 1 - 3 0 0 0}$ & 84 & 24,4 \\
& $\mathbf{3 0 0 1 - 4 0 0 0}$ & 22 & 6,4 \\
Sosyal Ağlarda Geçirilen Vakit & $\mathbf{2}$ saatten az & 13 & 3,8 \\
& $\mathbf{2}$ ile 4 saate kadar & 161 & 46,8 \\
& $\mathbf{4}$ ile 7 saate kadar & 107 & 31,1 \\
Yaş Ortalaması $=21,04$ & $\mathbf{7}$ saat ve üzeri & 47 & 13,7 \\
\end{tabular}

Her ankette sorular aynı olmakla beraber marka kullanıcılarına yönelik olduğundan dolayı sadece marka isimleri değiştirilmiştir. Her marka ile ilgili anket 150 kişiye uygulanmış ve toplamda 600 anket toplanmıştır. Verilerin sağlıklı çıkması için tüm sınıflara eşit sayıda dağıtılıp cevaplar alınmıştır. Anket bizzat araştırmacı tarafından Amasya Üniversitesinde eğitim gören öğrencilere uygulanmıştır. Doğru verileri elde etmek için tüm sınıflara eşit sayıda anket dağıtılmıştır. Araştırmacı tarafından öğrencilere öncelikle hangi markayı kullandıkları sorulmuş ve verilen cevaplara göre sadece Turkcell, Vodafone, Adidas ve Nike kullanıcılarına anketler dağıtılmıştır. Anket çalışmasında doğrudan markayı kullanan ve markanın sosyal medya hesaplarını düzenli olarak takip eden bireylere ulaşarak sorulara doğu ve güvenilir cevaplar amaçlanmıştır. Anketler dağıtıldıktan sonra araştırmacı tarafından anket hakkında bilgilendirme yapılmış, anlaşılmayan hususlar açıklanmıştır. Ortalama olarak 20 dakika cevaplama süresi verilmiştir. Yapılan 
anketler cevaplandıktan sonra hemen incelenmiş eksik ya da doğruluğuna güvenilmeyen anketler araştırma kapsamına alınmamıştır. Araştırma model ve hipotezlerinin test edilebilmesi amacıyla açıklayıcı, doğrulayıcı faktör analizleri ile doğrusal regresyon analizleri yapılmıştır. Toplanan anketlerin verilerinin bilgisayara aktarılması ve analizler için SPSS 20.0 ve LISREL 8.7 paket programları kullanılmıştır.

\section{BULGULAR}

\subsection{Açıklayıcı ve Doğrulayıcı Faktör Analizi ile Geçerlilik/Güvenilirlik Analizi Sonuçları}

Kim ve Ko'nun (2012) makalelerinde tüketicilerin sosyal medya pazarlama aktivitelerine katılımlarının (TSMPAK) tek bir boyut altında değil 5 başlık altında toplanılmasının uygun olduğunu ifade etmişlerdir. Öncelikle sosyal medya pazarlama aktivitelerine katılımın 11 değişkeninin tek bir boyut altında toplanıp toplanılmadığına bakılmıştır. Tek bir boyut altında açıklayıcı faktör analizi sonuçlarına göre Kaiser Meyer Olkin (KMO) değeri 0,847 ve Bartlett küresellik testi sonucu 0,000 (Yaklaşık ki-kare=1,349 ve sd: 55) olarak bulunmuştur ve sınır değerlerin oldukça üzerindedir $(>0,70$ ve $p<0,05)$. Tek bir boyut altında açıklanan varyans değeri ise 41,614 'dür. Harman'ın yaklaşımı da düşünüldüğünde araştırma verileri için de tek bir boyuttan ziyade bu 11 değişkenin farklı sayıdaki boyutlar ile açıklanması daha uygun olacaktır. Bu amaçla açıklayıcı faktör analizi tekrarlanmış ve Kim ve Ko'nun (2012)'nun çalışmalarında ifade ettikleri gibi beş boyutta değerlendirilmiştir. Tablo 2'de örtük değişkenler, gözlenen değişkenler ile beş boyut şeklinde hesaplanan açıklayıcı faktör analizi sonuçlarına yer verilmiştir.

Tablo 2: Tüketicilerin Sosyal Medya Pazarlama Aktivitelerine Katılımlarına İlişkin Açıklayıcı Faktör Analizi Sonuçları ve İç Tutarlılık Değerleri

\begin{tabular}{|c|c|c|c|c|c|c|}
\hline $\begin{array}{c}\text { Örtük } \\
\text { Değişkenler }\end{array}$ & $\begin{array}{c}\text { Gözlenen } \\
\text { Değişkenler }\end{array}$ & $\begin{array}{l}\text { Açıklanan } \\
\text { Varyans }\end{array}$ & $\begin{array}{c}\text { Öz } \\
\text { Değer }\end{array}$ & $\begin{array}{l}\text { Cronbach's } \\
\text { Alpha } \\
\text { Değeri }\end{array}$ & $\boldsymbol{\beta}$ & $\mathbf{t}$ \\
\hline \multirow[t]{2}{*}{ EĞLENCE } & X Markasının sosyal medya araçları eğlencelidir. & 86,710 & 1,734 & 0,846 & 0,88 & 17,70 \\
\hline & $\begin{array}{l}\text { X Markasının sosyal medya araçlarının içeriği ilgi } \\
\text { çekicidir }\end{array}$ & & & & 0,84 & 16,71 \\
\hline \multirow[t]{3}{*}{ ETKILEŞiM } & $\begin{array}{l}\text { XMarkasının sosyal medya araçları, diğerleri ile } \\
\text { bilgi paylaşma imkânı sunmaktadır. }\end{array}$ & 58,511 & 1,755 & $0,731^{*}$ & ---- & ---- \\
\hline & $\begin{array}{l}\text { X Markasının sosyal medya araçları sayesinde } \\
\text { diğerleri ile sohbet ve fikir paylaşımı } \\
\text { yapılabilmektedir. }\end{array}$ & & & & 0,69 & 13,19 \\
\hline & $\begin{array}{l}\text { X Markasının sosyal medya araçları görüşlerimi } \\
\text { paylaşmak oldukça kolaydır. }\end{array}$ & & & & 0,83 & 16,13 \\
\hline \multirow[t]{2}{*}{ MODAYI TAKIP } & $\begin{array}{l}\text { X Markasının sosyal medya araçlarında her } \\
\text { zaman en yeni bilgiler yer almaktadır. }\end{array}$ & 78,590 & 1.572 & 0,725 & 0,73 & 14,33 \\
\hline & $\begin{array}{l}\text { X Markasının sosyal medya araçlarını kullanmak } \\
\text { oldukça trenddir. }\end{array}$ & & & & 0,78 & 15,50 \\
\hline \multirow[t]{2}{*}{ KişiSELLEŞTIRME } & $\begin{array}{l}\text { X Markasının sosyal medya araçları, } \\
\text { kişiselleştirilmiş bilgi arama imkanı sunmaktadır. }\end{array}$ & 78,880 & 1,578 & 0,728 & 0,85 & 17,82 \\
\hline & $\begin{array}{l}\text { X Markasının sosyal medya araçları kişileştirilmiş } \\
\text { hizmet sunumu sağlamaktadır. }\end{array}$ & & & & 0,84 & 17,46 \\
\hline \multirow{2}{*}{$\begin{array}{l}\text { SOSYAL MEDYAYI } \\
\text { KULLANARAK } \\
\text { KULAKTAN } \\
\text { KULAĞA ILETişIM } \\
\text { (SMKKKI) }\end{array}$} & $\begin{array}{l}\text { X Markasının sosyal medya araçlarını kullanarak, } \\
\text { marka, ürün ya da hizmetler hakkındaki bilgileri } \\
\text { arkadaşlarıma aktarmaktan hoşlanıım. }\end{array}$ & 70,562 & 1,411 & $0,582^{* *}$ & ---- & ---- \\
\hline & $\begin{array}{l}\text { Kendi blog ve sayfalarımda, X Markasının sosyal } \\
\text { medya içeriklerini paylaşmak isterim. }\end{array}$ & & & & ---- & ---- \\
\hline
\end{tabular}

Tablo 2'deki sonuçlara bakıldığında (açıklanan varyans değerinin $\% 50$ 'den, öz değer oranının 1 'den ve Gronbach's Alpha değerinin de 0,70'den büyük bir oran olması gerekmektedir) eğlence, etkileşim, modayı takip, kişiselleştirme ve sosyal medyayı kullanarak kulaktan kulağa iletişim yer almaktadır. Bu değişkenlere tek tek baktığımızda; Eğlence yapısı $\% 86,710$ açıklanan varyans değerine, 1.734 öz değer oranına, 0.846 Cronbach's Alpha değerine sahiptir. Etkileşim yapısını ölçmek için sorulan üç soruda 
analizde kullanıldığında açıklanan varyans değeri $\% 58,511$, öz değer oranı 1,755 ve Cronbach's Alpha değeri 0,539 çıkmaktadır. "X Markasının sosyal medya araçları, diğerleri ile bilgi paylaşma imkânı sunmaktadır." sorusu çıkartıldığında Croncach's Alpha değeri 0,731 olmaktadır. Bu sebeple bu soru analizden çıkartıımış, ilerleyen adımlarda kullanılmamıştır. Modayı takip yapısının açıklanan varyans değeri \%78,590, öz değer oranı 1,572, Cronbach's Alpha değeri 0,725 'dir. Kişiselleştirme yapısında açıklanan varyans oranı $\% 78,880$, öz değer oranı 1,578 , Cronbach's Alpha değeri 0,728'dir. Yukarıdaki tablonun son yapısı olan sosyal medyayı kullanarak kulaktan kulağa iletişim yapısına baktığımızda açıklanan varyans değeri \%70,562, öz değer oranı 1,411 ve Cronbach's Alpha değeri 0,582'dir. Bu değişkende Cronbach's Alpha'da güvenilirlik değeri 0,70 'in altında kaldığı için analizlerde modelden çıkartılmıştır.

Araştırma modelinde yer alan ve tüketicilerin sosyal medya pazarlama aktivitelerine katılımlarının belirleyicileri ve etkileyicileri örtük değişkenlere ilişkin açıklayıcı faktör analizi sonuçları ile iç tutarlıık değer- lerine baktığımızda Tablo 3'deki sonuçlara ulaşılmıştır. Bu oranlara baz alarak örtük değişkenler üzerinde yapılan açıklayıcı faktör analizlerine baktığımızda tekrar satın alma niyeti yapısının açıklayıcı varyans değerinin \% 63,915, öz değer oranının 1,917, Cronbach's Alpha değerinin 0,708 olduğu görülmektedir. Kulaktan kulağa iletişim yapısının açıklayıcı varyans değeri \% 71,672, öz değer oranı 2,150, Cronbah's Alpha değeri 0,802'dir. Ürün ilgilenimi yapısına ilişkin açıklayıcı varyans değeri \% 85,744, öz değer oranı 2,572, Cronbach's Alpha değeri 0,917, marka güveninin açıklayıcı varyans değeri \% 83,949, öz değer oranı 3,358 ve Cronbach's Alpha değeri 0,936'dır. Hatırlamaya değer tecrübeler yapısını ölçmek için sorulan üç soru göz önüne alındığında açıklayıcı varyans değeri $\%$ 60,995, öz değer oranı 1,830, Cronbach's Alpha değeri 0,518 olarak hesaplanmıştır. Cronbach's Alpha değeri 0,70'nin altında kaldığından dolayı HDT2 yani "Turkcell'i düşündüğümde, zihnime olumlu şeyler gelmektedir". sorusu değerlendirmeden çıkarılmıştır ve daha sonrasında yapılan hesaplamalarda Cronbach's Alpha değeri 0,764 olarak hesaplanmıştır.

Tablo 3: TSMPAK'nın Etkileyicileri ve Sonuçlarına Illişkin Açıklayıcı Faktör Analizi Sonuçları ile İç Tutarlılık Değerleri

\begin{tabular}{|c|c|c|c|c|c|c|}
\hline $\begin{array}{c}\text { Örtük } \\
\text { Değişkenler }\end{array}$ & $\begin{array}{l}\text { Gözlenen } \\
\text { Değişkenler }\end{array}$ & $\begin{array}{l}\text { Açıklanan } \\
\text { Varyans }\end{array}$ & $\begin{array}{c}\text { Öz } \\
\text { Değer }\end{array}$ & $\begin{array}{c}\text { Cronbach's } \\
\text { Alpha } \\
\text { Değeri }\end{array}$ & $\beta$ & $\mathbf{t}$ \\
\hline \multirow[t]{3}{*}{$\begin{array}{l}\text { TEKRAR SATIN } \\
\text { ALMA NIYETI }\end{array}$} & $\begin{array}{l}\text { SAN1 X Markası bu hizmet kategorisinde tercih } \\
\text { ettiğim tek firmadır. }\end{array}$ & 63,915 & 1,917 & 0,708 & 0,54 & 10,16 \\
\hline & $\begin{array}{l}\text { SAN2 Fiyatlar biraz artsa dahi, X Markasının } \\
\text { hizmetlerinden yararlanmaya devam edeceğim. }\end{array}$ & & & & 0,62 & 11,80 \\
\hline & $\begin{array}{l}\text { SAN3 Böyle bir hizmete ihtiyaç duyduğum anda da } \\
\text { yine X Markasını tercih edeceğim. }\end{array}$ & & & & 0,91 & 18,93 \\
\hline \multirow{3}{*}{$\begin{array}{c}\text { KULAKTAN } \\
\text { KULAĞA } \\
\text { ILETIŞiM }\end{array}$} & $\begin{array}{l}\text { KKİ1 Diğerlerine X Markasını tavsiye etmekten } \\
\text { hoşlanırım. }\end{array}$ & 71,672 & 2,150 & 0,802 & 0,84 & 18,02 \\
\hline & $\begin{array}{l}\text { KKi2 Tanıdığım insanlar ile X Markasının olumlu } \\
\text { yönlerini konuşmayı çok severim. }\end{array}$ & & & & 0,76 & 15,68 \\
\hline & $\begin{array}{l}\text { KKi3 Diğer insanları X Markasını kullanmaları } \\
\text { yönünde ikna etmeye çalışıyorum. }\end{array}$ & & & & 0,66 & 12,95 \\
\hline ÜRÜN & Üi1 Y Ürünlerine çok ilgiliyim. & 85,744 & 2,572 & 0,917 & 0,84 & 19,00 \\
\hline \multirow[t]{2}{*}{ ÍLGILENIMi } & Üi2 Y Ürünleri benim için çok önemlidir. & & & & 0,94 & 22,58 \\
\hline & Üi3 Y Ürünlerine karşı çok hevesliyimdir. & & & & 0,88 & 20,16 \\
\hline MARKA & MG1 X Markasına güvenirim. & 83,949 & 3,358 & 0,936 & 0,88 & 20,33 \\
\hline \multirow[t]{3}{*}{ GÜVENi } & MG2 X Markası dürüst bir firmadır. & & & & 0,89 & 20,67 \\
\hline & MG3 X Markası sağlam bir firmadır. & & & & 0,89 & 20,85 \\
\hline & MG4 X Markası güvenilir bir firmadır. & & & & 0,89 & 20,05 \\
\hline $\begin{array}{l}\text { HATIRLANMAYA } \\
\text { DEĞER }\end{array}$ & $\begin{array}{l}\text { HDT1 X Markası ile hatırlayabildiğim pek çok } \\
\text { tecrübem var. }\end{array}$ & 60,995 & 1,830 & $0,764^{*}$ & 0,66 & 12,53 \\
\hline & $\begin{array}{l}\text { HDT2 X Markasını düşündüğümde, zihnime olumlu } \\
\text { şeyler gelmektedir. }\end{array}$ & & & & --- & ---- \\
\hline & HDT3 X Markası ile ilgili güzel tecrübelerim var. & & & & 0,94 & 18,48 \\
\hline
\end{tabular}

* Eleme öncesi Cronbach's Alpha Değeri= 0,518 olduğundan italik yazı biçimli değişkenler analizlerden çıkartılmıştır. 


\subsection{Doğrulayıcı Faktör Analizi ve Geçerlilik Analizleri}

Açıklayıcı faktör analizinin ardından, yapılar ve bu yapıları ölçen değişkenlerin yakınsak ve ayrım geçerliliği kriterleri açısından değerlendirilmesi yapılmıştır. Doğrulayıcı faktör analizi sonucunda gerçekleşen uyum iyiliği değerleri şu şekilde gerçekleşmiştir Kikare $=573,80, \mathrm{SD}=254$, Ki-kare $/ \mathrm{SD}=2,26, \mathrm{RMSEA}=$ 0,061 , Normed Fit Index (NFI) $=0,95$, Non-Normed Fit Index (NNFI) $=0,97$, Comparative Fit Index (CFI) $=0,97$, Incremental Fit Index (IFI) $=0,97$, Relative Fit Index (RFI) = 0,95, Goodness of Fit Index (GFI) = 0,89 , Adjusted Goodness of Fit Index (AGFI) $=0,84$ ve Standardized RMR $=0.042$. Bu değerlere bakıldığında iyi derecede uyum iyiliği değerlerinin gerçekleştiği görülmektedir. Fornel ve Larcker (1981)'ın yakınsak ve ayrım geçerliliği kriterlerine göre geçerlilik ile güvenilirlik analizleri yapılmıştır. Yapılar arasındaki korelasyon, korelasyon kareleri ve AVE değerleri hesaplanmış ve aşağıdaki tabloda sonuçlar gösterilmiştir. Bu sonuçlara göre ayrım geçerliliğinin sağlandığı söylenebilir (AVE sonuçlarının yatay ve diken eksende en büyük sayı olması gerekmektedir). Bununla birlikte yakınsak geçerlilik için değişkenlerin kendi yapılarını açıklama gücü açısından 0,50'den yüksek standardize edilmiş katsayı değerlerinin bulunduğu görülmektedir. Bu da yakınsak geçerliliğin sağlandığı anlamına gelmektedir. Ayrıca iç geçerlilik için önceden hesaplanan Cronbach's Alpha ile Composite Reliability (CR) değerleri de beklenen değerlerden yüksek olduğu için kriterlerin sağlandığı söylenebilir. (CR değerinin 0,50'den, Cronbach's Alpha değerinin ise 0,70'den yüksek olması beklenmektedir).

Tablo 4: Örtük Değişkenlere Ait Korelasyon, Standart Sapma ve CR/AVE Değerleri

\begin{tabular}{lccccccccc}
\hline & EG & ET & MOD & Kiş & Üi & MG & HDT & SAN & KKi \\
\hline É̆ & 1 & $0,426^{* *}$ & $0,518^{* *}$ & $0,413^{* *}$ & 0,048 & $0,349^{* *}$ & $0,252^{* *}$ & $0,291^{* *}$ & $0,285^{* *}$ \\
ET & 0,181 & 1 & $0,540^{* *}$ & $0,526^{* *}$ & $0,166^{* *}$ & $0,192^{* *}$ & $0,279^{* *}$ & $0,229^{* *}$ & $0,249^{* *}$ \\
MOD & 0,268 & 0,291 & 1 & $0,522^{* *}$ & $0,182^{* *}$ & $0,413^{* *}$ & $0,375^{* *}$ & $0,397^{* *}$ & $0,418^{* *}$ \\
Kiş & 0,170 & 0,276 & 0,272 & 1 & $0,113^{*}$ & $0,269^{* *}$ & $0,231^{* *}$ & $0,311^{* *}$ & $0,282^{* *}$ \\
Üi & 0,002 & 0,027 & 0,033 & 0,036 & 1 & $0,191^{* *}$ & $0,264^{* *}$ & 0,058 & $0,113^{*}$ \\
MG & 0,121 & 0,036 & 0,170 & 0,072 & 0,036 & 1 & $0,560^{* *}$ & $0,495^{* *}$ & $0,548^{* *}$ \\
HDT & 0,063 & 0,077 & 0,140 & 0,053 & 0,069 & 0,313 & 1 & $0,379^{* *}$ & $0,518^{* *}$ \\
SAN & 0,084 & 0,052 & 0,157 & 0,096 & 0,003 & 0,245 & 0,143 & 1 & $0,608^{* *}$ \\
KKi & 0,081 & 0,062 & 0,174 & 0,079 & 0,012 & 0,300 & 0,268 & 0,369 & 1 \\
Ort & 4,16 & 4,26 & 4,43 & 4,22 & 4,21 & 4,64 & 4,16 & 3,88 & 3,83 \\
Stan.Sa & 1,52 & 1,53 & 1,49 & 1,57 & 1,74 & 1,66 & 1,58 & 1,60 & 1,63 \\
CR & $\mathbf{0 , 8 5}$ & $\mathbf{0 , 7 4}$ & $\mathbf{0 , 6 4}$ & $\mathbf{0 , 8 3}$ & $\mathbf{0 , 9 1}$ & $\mathbf{0 , 9 4}$ & $\mathbf{0 , 7 9}$ & $\mathbf{0 , 7 4}$ & $\mathbf{0 , 8 0}$ \\
AVE & $\mathbf{0 , 7 3}$ & $\mathbf{0 , 5 8}$ & $\mathbf{0 , 5 7}$ & $\mathbf{0 , 7 1}$ & $\mathbf{0 , 7 8}$ & $\mathbf{0 , 7 8}$ & $\mathbf{0 , 6 6}$ & $\mathbf{0 , 5 0}$ & $\mathbf{0 , 5 7}$ \\
\hline
\end{tabular}

** 0,01 düzeyinde korelasyon anlamlı olarak bulunmuștur.

* 0,05 düzeyinde korelasyon anlamlı olarak bulunmuştur.

İtalik yazı biçimi ile gösterilen değerler ise korelasyon değerlerinin kareleridir.

4.3. Yapısal Eşitlik Modeli ile Araştırma Model ve Hipotezlerin Sınanması

Açıklayıcı ve Doğrulayıcı faktör analizleri ile birlikte geçerlilik/güvenilirlik çalışmaları yapıldıktan sonra,
Şekil 1'de daha önce gösterilen araştırma model ve hipotezlerinin test edilmesi için dört farklı tüketicilerin sosyal medya pazarlama aktivitelerine katılımlarına ilişkin yapısal eşitlik modelleri hesaplanmıştır. 
Table 5: Yapısal Eşitlik Modellerine Illişkin Katsayı ve t Değerleri

\begin{tabular}{|c|c|c|c|c|}
\hline Modeller & Örtük Değişkenler Arasındaki İlişki & Standardize Edilmiş Katsayı Değeri $\beta$ & t Değeri & $\begin{array}{l}\text { Hipotez } \\
\text { Sonucu }\end{array}$ \\
\hline Model 1 & Üi -> EĞ & $-0,10$ & $-1,92$ & RET \\
\hline \multirow{4}{*}{ (EĞ) } & MG -> EĞ & 0,46 & 5,06 & KABUL \\
\hline & HDT -> EĞ & 0,39 & 4,34 & KABUL \\
\hline & $E \check{G}->S A N$ & 0,84 & 6,14 & KABUL \\
\hline & EĞ $->$ KKI & 0,92 & 7,43 & KABUL \\
\hline Model 2 & ÜI -> ET & $-0,08$ & $-1,50$ & RET \\
\hline \multirow[t]{4}{*}{ (ET) } & MG -> ET & 0,40 & 3,64 & KABUL \\
\hline & HDT $->$ ET & 0,43 & 3,64 & KABUL \\
\hline & ET $->$ SAN & 0,84 & 4,31 & KABUL \\
\hline & $\mathrm{ET}->\mathrm{KKI}$ & 0,95 & 4,68 & KABUL \\
\hline Model 3 & Üi -> MOD & $-0,06$ & $-1,26$ & RET \\
\hline \multirow{4}{*}{ (MOD) } & MG $->$ MOD & 0,43 & 5,20 & KABUL \\
\hline & HDT -> MOD & 0,42 & 4,87 & KABUL \\
\hline & MOD -> SAN & 0,84 & 6,91 & KABUL \\
\hline & MOD $->\mathrm{KKI}$ & 0,91 & 8,83 & KABUL \\
\hline Model 4 & Üi -> Kiş & $-0,08$ & $-1,65$ & RET \\
\hline \multirow[t]{4}{*}{ (Kiş) } & MG -> Kiş & 0,42 & 4,64 & KABUL \\
\hline & HDT -> Kiş & 0,42 & 4,39 & KABUL \\
\hline & KIŞ -> SAN & 0,86 & 6,11 & KABUL \\
\hline & Kiş -> KKi & 0,91 & 7,27 & KABUL \\
\hline
\end{tabular}

Bulgulara göre Model 1 de, tüketicilerin eğlence amacı ile işletmelerin uyguladıkları sosyal medya pazarlama aktivitelerine katılım nedenleri etkileyen en önemli faktör marka güvenidir $(\beta=0,46)$. Diğer önemli değişken ise tüketicilerin işletme ile yaşadıkları hatırlamaya değer tecrübelerin olumluluğudur $(\beta=0,39)$. Ancak tüketicilerin ürün ilgilenimi, işletmelerin uygulayacakları sosyal medya pazarlama aktivitelerine katılımları istatistiki olarak etkilememektedir (t değeri=-1,92). İlgilenimi düşük olan tüketiciler, eğlenceli olduğu için sosyal medya pazarlama aktivitelerine katılmaktadır. Sonuçlara bakıldığında, eğlence için işletmelerin sosyal medya pazarlama aktivitelerine katılan tüketicilerin hem satın alma niyetlerinin $(\beta=0,84)$. hem de kulaktan kulağa iletişimlerinin $(\beta=0,92)$ oldukça olumlu yönde değişeceği sonucuna ulaşılmıştır.

Model 2'ye bakıldığında, tüketicilerin diğerleri ile etkileşim kurmak için işletmelerin sosyal medya pazarlama aktivitelerine katılımlarını etkileyen faktörlerden araştırma modelinde yer alan ürün ilgilenimin yine bir öneminin olmadığı görülmektedir (t değeri=-1,50). Marka güveni $(\beta=0,40)$ ve hatırlamaya değer tecrübeler $(\beta=0,43)$ ise tüketicilerin etkileşim için işletmelerin uygulayacakları sosyal medya pazarlama aktivitelerine katılımlarını olumlu yönde etkilemektedir. Etkileşim için katılım gösteren tüketicilerin hem satın alma niyetleri $(\beta=0,84)$ hem de kulaktan kulağa iletişim eğilimlerinin $(\beta=0,95)$ yüksek olduğu görülmektedir. Bu da işletmelerin eğlence ile birlikte etkileşim faktörünün kendi uygulamaları gereken sosyal medya pazarlama aktivitelerinin içeriği açısından önemini ortaya koymaktadır.

Model 3'de ise modayı takip etmek için işletmelerin sosyal medya pazarlama aktivitelerine katılımın üzerinde ürün ilgilenimi, marka güveni ve hatırlamaya değer tecrübelerin etkisi ile sonuç olarak da satın alma niyeti ve kulaktan kulağa iletişim ele alınmıştır. Bulgulara göre diğer iki modele benzer biçimde ürün ilgileniminin modayı takip için sosyal medya pazarlama aktivitelerine katılımı yordamadığı (t değeri=-1,20) görülmektedir. Bununla birlikte hem marka güveninin $(\beta=0,43)$ hem de hatırlamaya değer tecrübelerin $(\beta=0,42)$ modayı takip için tüketicilerin sosyal medya pazarlama aktivitelerini olumlu yönde yordadığı saptanmıştır. Modayı takip için de sosyal medya pazarlama aktivitelerine katılım gösteren tüketicilerin hem satın alma niyetleri $(\beta=0,84)$ hem de kulaktan kulağa iletişime $(\beta=0,91)$ yatkınlıkları oluşmaktadır. 
Model 4'de ise işletmelerin uyguladıkları sosyal medya pazarlama aktivitelerine kişiselleştirilmiş hizmet için katılan tüketicilerin marka güveninden ve hatırlaya değer tecrübelerden $(\beta=0,42)$ etkilendikleri saptanmıştır. Kişiselleştirilmiş hizmet için tüketicilerin sosyal medya pazarlama aktivitelerine katılım gösteren tüketiciler hem satın alma niyeti $(\beta=0,86)$ hem de kulaktan kulağa iletişime $(\beta=0,91)$ yatkın olmaktadır. Tablo 6'da dört farklı araştırma modeline ilişkin uyum iyiliği değerleri yer almaktadır. Sonuçlara bakıldığında tüm modellerin uyum iyiliği değerlerin uygun olduğu görülmektedir.

Table 6: Yapısal Eşitlik Modellerine Illişkin Uyum İyiliği Değerleri

\begin{tabular}{lcccccccc}
\hline Modeller & $\mathbf{X}^{2}$ & Sd & GFI & CFI & AGFI & NFI & RMSEA & SRMR \\
\hline $\begin{array}{l}\text { Model 1 } \\
\text { (EĞ) }\end{array}$ & 700,46 & 210 & 0,85 & 0,94 & 0,80 & 0,92 & 0,083 & 0,084 \\
$\begin{array}{l}\text { Model 2 } \\
\text { (ET) }\end{array}$ & 738,29 & 210 & 0,84 & 0,95 & 0,79 & 0,93 & 0,086 & 0,093 \\
$\begin{array}{l}\text { Model 3 } \\
\text { (MOD) }\end{array}$ & 688,00 & 210 & 0,85 & 0,95 & 0,80 & 0,93 & 0,081 & 0,085 \\
$\begin{array}{l}\text { Model 4 } \\
\text { (Kiş) }\end{array}$ & 821,76 & 210 & 0,83 & 0,94 & 0,77 & 0,93 & 0,092 & 0,090 \\
\hline
\end{tabular}

\section{SONUÇ VE ÖNERILER}

Günümüzde tüketiciler radyo, televizyon, gazete ve dergi gibi temel kaynakları bırakıp bilgi arama ve satın alma kararı açısından sosyal medya araçlarına yönelmektedir (Vollmer ve Precourt, 2008). Bu nedenle, tüketiciler ile etkili iletişim kurma çabası işletmelerin sosyal medyayı kullanma isteklerini giderek artırmaktadır ve sosyal medyanın genişlemesi pazarlama uygulamalarını doğrudan etkilemektedir (Habibi vd. 2014). İşletmelerin sadık müşteri oluşturma ve müşteri ile uzun süreli iletişim kavramları modern pazarlama anlayışının odak noktalarıdır. Sosyal medya araçlarının etkin kullanımının bu iki sonucu destekler nitelikte olması elbette ki işletmelerin bu araçları kullanım arzularındandır. Yapılan çalışmada, tüketicilerin işletmelerin uyguladıkları sosyal medya pazarlama aktivitelerine katılımlarının nedenleri olarak eğlence, etkileşim, modayı takip ve kişiselleştirme olduğu belirlenmiştir. İşletmeler tüketicilerin ilgisini çekebilmek için bu dört özelliğe göre içerik ve uygulama hazırlamaları gerekmektedir.
Aslında bu katılımlarında belirleyicileri vardır. Çalışma bulgularında hem marka güveni hem de hatırlamaya değer tecrübelerin, tüketicilerin sosyal medya pazarlama aktivitelerine katılımlarını olumlu yönde etkiledikleri sonucuna ulaşılmıştır. İşletmeler tüketiciler güven verdikleri ve onlara hatırlamaya değer tecrübeler sundukları sürece, uygulayacakları sosyal medya pazarlama aktivitelerine katılımlarını da artırabilirler. Son olarak ise eğlence, etkileşim, modayı takip ve kişiselleştirme için sosyal medya pazarlama aktivitelerine katılım gösteren tüketicilerin hem satın alma davranışları hem de kulaktan kulağa iletişime yatkınları da artmaktadır. Bu çalışmanın sınırlılıkları ise genel tüketicilerden ziyade sadece üniversite öğrencilerinin çalışmaya dahil edilmesidir. Ayrıca veri kontrolü sonucunda kadın öğrencilerin erkeklere kıyasla geçerli örneklemi oluşturmasıdır. İleride yapılacak çalışmalarda daha geniş tüketici grupları ile benzer bir çalışmanın yapılmasında fayda vardır.

\section{KAYNAKLAR}

Agapito, D., Mendes, J., ve Valle, P. (2013) "Exploring the Conceptualization of the Sensory Dimension of Tourist Experiences". Journal of Destination Marketing and Management, 2(2), 62-73.

Allsop, D. T., Bassett, B. R., ve Hoskins, J. A. (2007) “Wordof-mouth Research: Principles and Applications". Journal of Advertising Research, 47(4), 398-411.
Braunsberger, K. ve Munch, J. M. (1998)"Source Expertise Versus Experience Effects in Hospital Advertising", Journal of Services Marketing, 12(1), 23-38.

Carroll, B.A. ve Ahuvia, A.C. (2006) "Some Antecedents and Outcomes of Brand Love", Marketing Letters, 17(2), 79-89. 
Celsi, R. ve Olson, J. (1988) "The Role of Involvement in Attention and Comprehension Processes", Journal of Consumer Research, 15, 210-224.

Chaudhuri, A. ve Holbrook, M. B. (2001) "The Chain of Effects from Brand Trust and Brand Affect to Brand Performance: The Role of Brand Loyalty", Journal of Marketing, 65(2), 81-93.

Chiu, C. M., Huang, H. Y., ve Yen, C. H. (2010) "Antecedents of Online Trust in Online Auctions","Electronic Commerce Research and Application", 9, 148-159.

Delgado-Ballester, E. ve Luis Munuera-Alemán, J. (2005) "Does Brand Trust Matter to Brand Equity?", Journal of Product and Brand Management, 14(3), 187-196.

Dholakia, U. M. (1998) "Involvement-response Models of Joint Effects: An Empirical Test and Extension", Advances in Consumer Research, 25(1), 499-506.

Ha, H. Y. ve Perks, H. (2005) "Effects of Consumer Perceptions of Brand Experience on the Web: Brand Familiarity, Satisfaction and Brand Trust". Journal of Consumer Behaviour, 4(6), 438-452.

Habibi, M. R., Laroche, M., ve Richard, M. O. (2014) "The Roles of Brand Community and Community Engagement in Building Brand Trust on Social Media". Computers in Human Behavior, 37, 152-161.

Harris, R. (2009) "Social Media Ecosystem Mapped as a Wiring Diagram", http://www.twitterthoughts. com/social-media-newsanalyses/2009/9/3/socialmediaecosystem-mapped-as-a-wiringdiagram.html? printerFriendly=true.

Harvin, R. (2000) "In Internet Branding: The Off-Lines Have It", Brandweek, 41 (4), 30-31.

Hellier, P. K., Geursen, G. M., Carr, Rodney A. ve Rickard, J. A. 2003" "Customer Repurchase Intention: A General Structural Equation Model", European Journal of Marketing, 37(11), 1762-1800.

Helmig, B., Huber, J. A., ve Leeflang, P. (2007)“Explaining Behavioural Intentions toward Co-Branded Products". Journal of Marketing Management, 23(3-4), 285-304.

Hennig-Thurau, T., Gwinner, K. P., Walsh, G., ve Gremler, D. D. (2004) "Electronic Word-of-mouth via ConsumerOpinion Platforms: What Motivates Consumers to Articulate Themselves on the Internet?". Journal of Interactive Marketing, 18(1), 38-52.

Kaplan, A. M., ve Haenlein, M. (2010) “Users of the World, Unite! The Challenges and Opportunities of Social Media", Business Horizons, 53(1), 59-68.
Kim, A. J. ve Ko, E. (2012) “Do Social Media Marketing Activities Enhance Customer Equiy? An Empirical Study of Luxury Fashion Brand", Journal of Business Research, $65,1480-1486$.

Williams, L. ve Cothrell, J. (2000) "Four Smart Ways to Run Online Communities", Sloan Management Review, 41, 81-91

Lang, B. (2010) "Ipsos OTX Study: People Spend More Than Half Their Day Consuming Media", http://www. thewrap.com/node/21005.

Mangold, W. G. ve Faulds, D. J. (2009)"Social media: The New Hybrid Element of the Promotion Mix". Business Horizons, 52(4), 357-365.

Norback, M. (2005) "Cross-promoting and branding of media product portfolios", in Picard, R.G. (Ed.), Media Portfolios, Issues in Management of Multiple Products and Services, Lawrence Erlbaum Associates, Mahwah, NJ, 139-166.

Powers, T., Advincula, D., Austin, M. S., Graiko, S., ve Snyder, J. (2012) "Digital and Social Media in the Purchase Decision Process: A Special Report from the Advertising Research Foundation", Journal of Advertising Research, 52(4), 479-489.

Sarason, S. B. (1974) The Psychological Sense of Community: Prospects for the Community Psychology, Jossey-Bass, San Francisco.

Stokburger-Sauer, N., Ratneshwar, S., ve Sen, S. (2012) "Drivers of Consumer-Brand Identification", International Journal of Research in Marketing, 29(4), 406-418.

Trusov, M., Bucklin, R. E., ve Pauwels, K. (2009) “Effects of Word-of-mouth versus Traditional Marketing: Findings from an Internet Social Networking Site", Journal of Marketing, 73(5), 90-102.

Vollmer, C. ve Precourt, G. (2008) Always on: Advertising, Marketing, and Media in an Era of Consumer Control. New York: McGraw-Hill.

Warrington, P., ve Shim, S. (2000) "An Empirical Investigation of the Relationship between Product Involvement and Brand Commitment", Psychology and Marketing, 17(9), 761-782.

Williams, R. L. ve Cothrel, J. (2000) "Four Smart Ways to Run Online Communities", MIT Sloan Management Review, 41(4), 81.

Zeithaml, V.A., Berry, L., ve Parasuraman, A. (1996) “The Behavioral Consequences of Service Quality", Journal of Marketing, 60(2), 31-46. 